\title{
Analysis of The Marriage Treaty and Legal Approach Due Judging from The Draft of Civil Code
}

Takwim Azami ${ }^{1}$ and Akhmad Khisni ${ }^{2}$

\begin{abstract}
The continued development of the situation in society at large prospective marriage couples who decided to make a marriage agreement. This is because both the men and women capable of generating wealth each and there are many other reasons why it made a pact to marry. Mating agreement is the agreement made by two people (prospective husband and wife) before marriage. Mating Agreement provided for in article 29 of Act No. 1 of 1974 marriage but with the birth of the constitutional court's decision No. 69 / PUU-XIII / 2015 there are some changes in the Marriage Covenant which is still a Pro Cons in society. The problems examined in this study is: how marital agreement in terms of the book of Civil Law. The method used is a normative legal approach. Source materials used law is the source of primary legal materials and sources of secondary legal materials such as books and law legal materials collection techniques performed by the document study reading and studying the legislation regulations. The analysis of legal materials in this study, conducted by processing and analyzing qualitative and descriptive poured. The result of the first conclusion that the arrangement agreement are married in Indonesia in the Act including the Civil Code, the Marriage Act No. 1 of 1974, KHI and the Constitutional Court Decision No. 69 / PUU-XIII / 2016.

Keywords: Marriage Agreement; Effects; Legal Approach.
\end{abstract}

\section{Introduction}

The Article 1 of Act No. 1 of 1974 on the marriage is inner and outer bond between a man and a woman as husband and wife with the aim of forming a family (household) who are happy and everlasting based on God. ${ }^{3}$ Basically marriage is none other than the events that contain rights and obligations, which once performed by a husband and wife will lead to legal consequences, among others emergence due to the personal rights and duties of husband and wife, due to property of husband and wife and as a result of marriage against children as offspring. The legal consequences which we will highlight in this paper are the legal consequences to property arising from the marriage, namely the emergence of marital property.

Regarding the marital property is regulated in article 119 to article 125 the Civil Code and in Act No. 1 of 1974 on marriage set out in article 35 to article 37. Although regulate the same thing, but there is a difference in the Book of Civil Law and Act No. 1 of 1974 on marriage in dealing with marital property. The Book of Civil Law adheres to the principle mixing round, this is indicated in article 119 the Civil Code which stated in the article that the start time of the marriage. In Act No.1 of 1974 on Marriage arranged on the mating agreement on Article 29.

- On or before the marriage took place, the two parties by mutual consent can hold a written agreement approved by the marriage registrar clerk, after which it shall also apply to third parties throughout the third party jam.

- The agreement can not be passed when breaking the boundaries of the law, religion and morality.

\footnotetext{
${ }^{1}$ Master of Notary's Student Sultan Agung Islamic University (UNISSULA) Semarang email takwimazami93@gmail.com

2 Lecturer of Faculty of Law UNISSULA

${ }^{3}$ Wantijk K. Saleh 1980 Hukum Perkawinan di Indonesian Ed. VI Ghalia Indonesia Jakarta p.14.
} 
- The agreement entered into force since the marriage took place.

- During the marriage lasted such agreements cannot be changed unless both parties consent to change and the change does not harm third parties. ${ }^{4}$

The mating written agreement made with the consent of both parties. This raises significant legal consequences for the parties have entered into the agreement and should not violate the agreement (1313BW). The parties must followed this agreement as set forth in BW. As a treaty then when one of the parties in violation (unpromisable) to do a good suit for divorce or compensation.

Agreement mating usually arranged before the holding of marriage. It aims to set up before their wedding. So that the rights and obligations of the parties will become evident. Making the agreement before marriage is that the agreement will be effective when the marriage took place. Because there is a possibility if the agreement executed after their marriage mate would be a strange thing. Because they only think of treasure while are mutually dependent. This means that there are indications for a divorce or marriage since the beginning the motivation is political or economic motivations.

Known for their marriage the marriage covenant which is often read future husband after the marriage ceremony namely Taklif Talaq. Other agreements are often made is an agreement on the Joint treasure. The marriage contract is an agreement made by the candidate both at the time or before the marriage took place, and each promised to obey what is in the agreement, which was ratified by the marriage registration.

Agreement must be authorized to marry a civil registry officer. Actually allowed to form an agreement personally or simply involve a third party. Then the agreement letter handed over to members of Aceh recording for approval. Mating agreement made as it was said legitimate but weak legal force.

Therefore, many people who made this agreement before a Notary using Notary agreement. If the agreement made with the notary the legal force of the agreement and unquestionably strong. ${ }^{5}$

Mating agreement can not be changed unilaterally but there must be agreement on both sides to change it. Humans sometimes changed his mind so that Marriage Acts to accommodate it within the provisions of Article 29 (4) Marriage Act. Changes also agreement must not involve a third party in the agreement. ${ }^{6}$

This of course, led to the writer wanted to know how people's lives on the making of the marriage contract made by a notary where prearranged according to Act No. 1 of 1974 as well as the legal consequences arising under the Civil Code.

\section{Research Methods}

Research methods used in writing is a normative juridical approach. Normative research is legal research done by researching library materials or secondary materials. ${ }^{7}$

\footnotetext{
${ }^{4}$ Sudarsono 1991 Hukum Perkawinan Nasional Rineka Cipta Jakarta p.7

${ }^{5}$ R. Soetojo Prawirohamidjojo 1998 Perkawinan campuran di Indonesia Airlangga University Press p.57.

${ }^{6}$ Ibid p. 60.

7 Sarjono Soekanto and Sri Mamuji 2007 Metodologi Penelitian Normatif Jakarta: Raja Grafindo Persada p.13.
} 


\section{Results And Discussion}

\subsection{Making The Marriage Agreement Made By A Notary And Legal Consequences Arising Under The Civil Code.}

Understanding agreements we can see in article 1313 Book of Civil Law. An agreement is an act by which one or more persons bind himself to one or more persons.

Marriage between a man and a woman according to the Book of the Law of Civil Law in Article 119 resulted happen round the assets marital union in this case in principle in a conjugal relationship that there is only one kind of property that is a treasure unity. Violations of the principle of unity property is made possible by the provisions of article 139 of the Civil Code that it gives the opportunity for husbands and wives to make arrangements to marry the contents set its own wealth origin of the agreement does not violate good morals or public order. ${ }^{8}$

For the fulfillment of a legal agreement, it must qualify the validity of a treaty which is regulated in Article 1320 of the Civil Code, namely:

- Agreed those that bind himself;

- prowess to make an engagement;

- A certain thing;

- One reason kosher.

The bottom line if desired agreement of the parties does not meet the terms of their agreements which have bound themselves and / or do not meet the skill to make a commitment, then the agreement is not valid. Then the agreement can be canceled. Whereas, if it does not meet the requirements of a particular case as well as a kosher because such agreement is null and void.

Mating agreement is a means to protect against property of the bride. Through this agreement the parties may determine the innate property of each. Is there segregation of assets since the beginning of the marriage or no joint property but arranged method of apportionment in the event of divorce. Treasure inherited from their respective husbands and wives and property derived respectively as a gift or inheritance, is under the control of each round the parties could not agree otherwise. ${ }^{9}$ Community property is property acquired in marriage. This conflict occurs when one party in divorce and division of property demands does not matter if the parties can compromise. What often happens in life is each determined to recognize his partner treasures. In Article 36 of the Marriage Act states that the husband or wife, each party may act on the mutual agreement on joint property in marriage. Husband and wife also has the full right to take legal actions regarding the innate property.

Then the mating agreement can load regulation concerning joint property and possessions default. Congenital treasure can be incorporated into common property. Community property in a marriage can be separated through mating agreement. For husband and wife were released to take legal action. Mating agreement made is not always just managed the property in marriage, but also regulate the rights and obligations of the parties. Trace in Article 34 of Act 1 of 1974, which reads:

"(1) The husband shall protect his wife and provide every necessity of home life according to his ability. (2). The wife shall manage the affairs of the household as well as possible.

(3). Where a spouse is shirking its obligations respectively the purpouses may file with the court."

\footnotetext{
${ }^{8}$ Hadikusuma Hilman 2007 Hukum Perkawinan di Indonesia Bandung: advanced city p.52.

${ }^{9}$ http://www.hukumonline.com/berita/baca/It58180e 2811d66 / plus-minus-decision-mk-oncovenant marriage was quoted on 17 June 2018 at: 9:34 pm
} 
A new marriage contract considered valid if it meets the terms and conditions set out in legislation. For the attention to this aspect is very important that the legal force of the marriage contract that can be justified.

Marital agreement can not be separated from the general agreement in addition to specifically as set out in the Marriage Act. In general terms the validity of the agreement, there are two kinds:

- Regarding the subject matter, includes:

- People who make a pact to be competent or able to take legal actions

- Agreement (consensus) on which agreement must be reached on the basis of the freedom to make his will.

- About the object, that is what is promised by each party.

To make a marriage contract must meet several requirements / conditions that are not unlawful, among others:

- Together with the approval of the agreement

- Husband and wife are proficient in making agreements

- Objects clear agreement

- Not contrary to law, religion and morality

- Expressed in writing and ratified by the VAT ${ }^{10}$

Through mating agreement can be set a few things that are considered substantial examples such as:

- Arrangements regarding the obligations of husband and wife in marriage.

- Such husband and wife shall be obliged to provide for his family takes care of family. Husband banned for abandoning the family for any reason.

- Prohibiting the use of violence in marriage.

- Domestic violence (domestic violence) became quite warm that issue today. Husband especially prohibited from communal violence against children or wife.

- Custody of children in case of divorce. Kids are often contested by his parents because of the article 41 (a) of the Marriage Act "Neither the mother or father will still be obliged to maintain and educate their children, solely based on the interests of the child;", on clearly regulated post-divorce child custody. ${ }^{11}$

Agreement marriage is only born by notarial agreement in which the birth certificate is a prerequisite for mating agreement, so that the mating agreement as described above shall be made by notarial agreement. In Article 38 paragraph (3) letter C Law Notary agreement confirms that the contents of the will of the client.

Although the contents of the agreement is the will of the parties and shall apply as laws that make it, but still the notary does not have to always grant the will or desire of the client that if contrary to the legislation, religious norms, moral, social and community, as well as public order.

Post-decision of the Court No.69 / PUU-XIII / 2015 agreement is a marriage made Notary simply replace the part premisse only. The notarial agreement must have the strength of evidence was perfect, if all procedures or procedures and conditions specified in UUJN met, and on the contrary can be proved to the lawsuit or court decision it may agreement canceled. Later in the marriage covenant which made in writing and ratified by the recording clerk marriage. The marriage contract invalid by recording employee or Notary. The marriage contract was held as law for those who make it, also applies to third parties throughout the third party.

\footnotetext{
${ }^{10}$ Ibid.

${ }^{11}$ Hazarin 1986 Tinjauan Hukum Perkawinan UU No. 1 of 1974 Jakarta Tintamas p.1.
} 
Through mating agreement can be determined who is entitled to the child care even if the divorce has been governed Taklik Talaq of marriage. However, the parties may portend the mating agreements which are listed in the notarial agreement. Since it has the force of law.

By law husband and wife shall be in love mutual respect, loyal and provide emotional and physical support that one to the other. Their mating agreement gave birth to the legal effect because the agreement desired by the parties. Mating agreement raises some effect. Legally the parties' mutual agreement related to the holding of mating and each must carry out the obligations and rights. The parties also must be ready with the legal consequences that would arise if a foul on mating agreement. Morally and psychologically mating agreement will induce a feeling of no confidence against his or her spouse. He will be shadowed by the fear that her partner in violation of the agreement. This anxiety will lead to unhappiness in running the household. ${ }^{12}$

\subsection{Legal Result Happens When the Covenant of Marriage Made According to the Civil Code}

When a marriage has been considered lawful will surely lead to the legal consequences of marriage, namely the emergence of rights and obligations for both parties. What is meant right here is nothing that is received by a person from the others, while the meaning of the obligation is to be done between one person and another person. In the marital relationship within the household, the husband nor the wife has the right and the right. Behind it the husband also has a duty that must be met as well as the wife also have an obligation:

- Husbands and wives must be faithful and helping (article 103 of the Civil Code)

- The husband and wife are obliged to maintain and educate their children (Article 104 of the Civil Code)

- Every husband is the head of the union of husband and wife (article 105 paragraph 1 of the Civil Code)

- Shall give help husband to his wife (article 105 paragraph 2 of the Civil Code)

- Each husband should take care of the personal property of his wife (article 105, paragraph 3 of the Civil Code)

- Every husband has the right take care of the assets together (Article 105 paragraph 4 of the Civil Code)

- Husband not allowed to change or encumber immovable assets of his wife without the consent of the wife (article 105, paragraph 5 of the Civil Code)

- Every wife should be submissive and obedient to her husband (Article 106 paragraph 1 of the Civil Code)

- Every wife must live with her husband (article 106 paragraph 2)

- Every man shall help his wife in front of judges (article 110 of the Civil Code)

- Each wife has the right to make a will without the husband's permission (Article 118 of the Civil Code)

In law marriage also explained the rights and responsibilities of husband and wife stated in Article 30 through Article 34 of the Marriage Act, which is essentially as follows:

- Each party has the right to take legal actions (Article 31, paragraph 2 of the Marriage Act)

- The husband is the head of the household and the wife is a housewife (article 31 paragraph 3 of Marriage Act)

\footnotetext{
12 Mulyoto 2012 Teknik Perjanjian Bagaimana Membuat dan hukumnya Horizon Media Yogyakarta p. 17
} 
- Determining the residence of husband and wife they (article 32 of the Marriage Act)

- The husband and wife ought to love, respect and mutually faithful (Article 33 of the Marriage Act)

- Husband shall protect his wife and provide everything according to his ability (Article 34 paragraph 1 of the Marriage Act)

- The wife shall manage the affairs of the household as well as possible (article 34 paragraph 2 of the Marriage Act)

- If a husband and wife respectively malpractice can file a lawsuit with the Court (article 34 paragraph 3 of Marriage Act)

Other than those rights and obligations there are other rights as a result of the marriage that is on the property in marriages. It is stated in Article 35 to Article 37 of the Marriage Act, which is where the point is:

- Arising innate property and community property

- Husband or wife each have a full right of property or congenital

- Husband or wife must always consent prior legal actions against community property

\section{Conclusion}

Based on the description of the case can be concluded that:

- Juridical Analysis of the marriage covenant making point when the desired agreement of the parties does not meet the terms of their agreements which have bound themselves and / or do not meet the skill to make a commitment, then the agreement is not valid. Then the agreement can be canceled.

- Agreement marriage is only born by notarial agreement in which the birth certificate is a prerequisite for mating agreement, so that the mating agreement as described above shall be made by notarial agreement. Stated in Article 38 paragraph (3) letter C of Law Notary agreement confirms that the contents of the will of the client.

\section{References}

[1] Wantijk K. Saleh 1980 Hukum Perkawinan di Indonesian Ed. VI Ghalia Indonesia Jakarta

[2] Sudarsono 1991 Hukum Perkawinan Nasiona/ Rineka Cipta Jakarta

[3] R. Soetojo Prawirohamidjojo 1998 Perkawinan campuran di Indonesia Airlangga University Press

[4] Sarjono Soekanto and Sri Mamuji 2007 Metodologi Penelitian Normatif Jakarta: Raja Grafindo Persada

[5] Hadikusuma Hilman 2007 Hukum Perkawinan di Indonesia Bandung: advanced city

[6] http://www.hukumonline.com/berita/baca/lt58180e 2811d66 / plus-minus-decisionmk-on-covenant marriage was quoted on 17 June 2018 at: 9:34 pm

[7] Hazarin 1986 Tinjauan Hukum Perkawinan UU No. 1 of 1974 Jakarta Tintamas

[8] Mulyoto 2012 Teknik Perjanjian Bagaimana Membuat dan hukumnya Horizon Media Yogyakarta

[9] http://www.hukumonline.com/berita/baca/lt58180e 2811d66 / plus-minus-decisionmk-on-covenant marriage, was quoted on 17 June 2018 at: 9:34 pm 